\title{
Myths and Realities about Mexico-United States Migration
}

\author{
Luis Arturo Rivas Tovar ${ }^{1 *}$, Adela Chávez², Juan Enrique Azuara Munguía², \\ Ana Gabriela Benítez Jurado ${ }^{2}$ \\ ${ }^{1}$ Institute Ortega y Gasset, Madrid, Spain \\ ${ }^{2}$ College of Commerce and Administration E.S.C.A, IPN, Mexico City, Mexico \\ Email: larivas33@ hotmail.com, adelita1122@yahoo.com.mx, jazuaram78@hotmail.com, \\ abenitezjurado@yahoo.com
}

Received 20 March 2014; revised 3 May 2014; accepted 20 May 2014

Copyright @ 2014 by authors and Scientific Research Publishing Inc.

This work is licensed under the Creative Commons Attribution International License (CC BY). http://creativecommons.org/licenses/by/4.0/

(c) (i) Open Access

\section{Abstract}

This is an article review of state-of-the-art about Mexicans' migration to the USA, in last 5 years. We analyzed 4 myths: 1). Migration generates negative effects for the receiving country because when migrants arrive. 2). Mexicans' migration to the USA generates big distortions in the receiving communities and Mexico is the only economic beneficiary. 3). Migrants collapse public health services in USA. 4). Mexican migrants are mistreated by American authorities. The findings will show the lack of empirical evidence of these generalized ideas.

\section{Keywords}

\section{Migration, Social Security, Remittances}

\section{Introduction}

In review literature about the topic, ("mexican immigration" to "USA") the more relevant works we can mentioned [1] Delgado \& Stefancic, (Eds.). (2000). This book contains the finest, highly accessible articles in the fast-growing legal genre of critical race theory - a field which is changing the way this nation looks at race, challenging orthodoxy, questioning the premises of liberalism, and debating about race theory in US context.

[2] Valdes, (1997). Analyzed race, ethnicity and national identity in Latinos immigrants in Law and American society. [3] Johnson, (1995). Wrote a multi cited essay about Immigration Politics, Popular Democracy, and California’s Proposition 187: He found the Political Relevance and Legal Irrelevance of Race.

[4] Henderson, (2011). Make an interesting historical review about Mexican Immigration to the United States. And also made a companion to Mexican History and Culture.

${ }^{*}$ Corresponding author. 
[5] Schwalbe, (2010). In his analysis of Mexican immigration to the United States (a Doctoral dissertation in University of Delaware) concluded that specifically, the recommendations include a more open guest worker program, a better verification system, and a simplification of policies so that they are more easily enforceable. Furthermore, this paper advocates expanding NAFTA and developmental aid to Mexico to motivate workers to stay in their country of origin.

[6] Martinez, \& Slack, (2013). Examine the social repercussions of criminally prosecuting individuals that cross into the United States without official documentation. The "criminalization of immigration law" (Coleman, 2007), federal- and state-level anti-immigrant initiatives, and an incarceration-oriented approach to dealing with unauthorized migration have redefined what it means to be undocumented in the United States, a definition with more sociological implications than ever before.

Finally, [7] Peri (2012). Analyzed the effect of immigration on productivity: Evidence from US states.

One of the major social impact processes in Mexico is the migration of a part of its population to the US, having as main objective, to improve their living conditions. He found no evidence that immigrants crowded out employment. At the same time, we find that immigration had a strong, positive association with total factor productivity and a negative association with the high skill bias of production technologies. The results are consistent with the idea that immigrants promoted efficient task specialization, thus increasing TFP, and also promoted the adoption of unskilled-efficient technologies.

\section{Mexican Immigrants in US}

It's estimated that in the USA. there are around 23 million Mexicans living in regular or irregular way, which constitutes the 20\% of Mexico's present population, nevertheless, as mentioned by [8] Koffi Annan (2006).

The migration phenomenon isn't recent, as since national borders exist, people have trespass them, not only to visit other countries but also to live and work on them. By doing this they've been always at risk, moved by the determination of defeating the adversity and having better living conditions. Historically, migration has helped the growth of welfare not only for migrants as individuals, but for the whole mankind.

Mexicans' migration to the US phenomenon's background dates back to more than a century and a half ago, a situationset by multiple factors, mainly; geographic, historical, economic and politic, however, this migration dynamic has been exacerbated by the economic situation that our country has been through since past century's '80s decade, bringing as consequence that 2004's population census showed more than nine million Mexicans living in the American Union (with probative documents), making them the first minority [9] (Zúñiga, Leite \& Nava, 2004).

In Mexico, migration to foreign countries is an issue from many years ago, migration starts mainly in the most poor and marginal geo-economic zones, the first documented data regarding massive migration shows that it started its development in the 20th century's '40s decade through "Bracero's" development program, and increasing by the decadence or decay of the accumulative pattern of the import substitution model through '40s '80s decades, characterized by the abandonment of the working lands, the market's opening through free trade agreements and the priority granted to the secondary sector, neoliberal politics' inertia, that remain to the present day ([10] Ramirez, 2003).

The distribution of migrants in the United States by state is shown in Figure 1.

According to what's shown in Figure 1, and information from [11] the American Community Survey (2010) information, we can deduce that:

1) More than $83 \%$ of the Mexican-Born reside in only 10 states.

2) More than 7 out of 10 migrants in New Mexico State were Mexicans in 2006.

3) The size of Mexican population in South Dakota, Louisiana, Alaska and Ohio States doubled from the year 2000 to 2006.

4) More than a quarter of the migrant Mexican-Born population arrived to the US in the year 2000 or later.

5) Three quarters of Mexican migrants in 2006 were adults in working age.

6) One out of 5 migrants was naturalized as American Citizens in 2006.

7) Almost $75 \%$ of Mexican migrants have poor English language knowledge.

8) 3 out of 5 Mexican migrants only have elementary school studies.

It is worth mentioning that, in December's 18th 2013 United Nations General Assembly was enacted the Migrant's International Day and by this, [12] Instituto Nacional de Geografía (2011) (Mexican Statistics and Geo- 


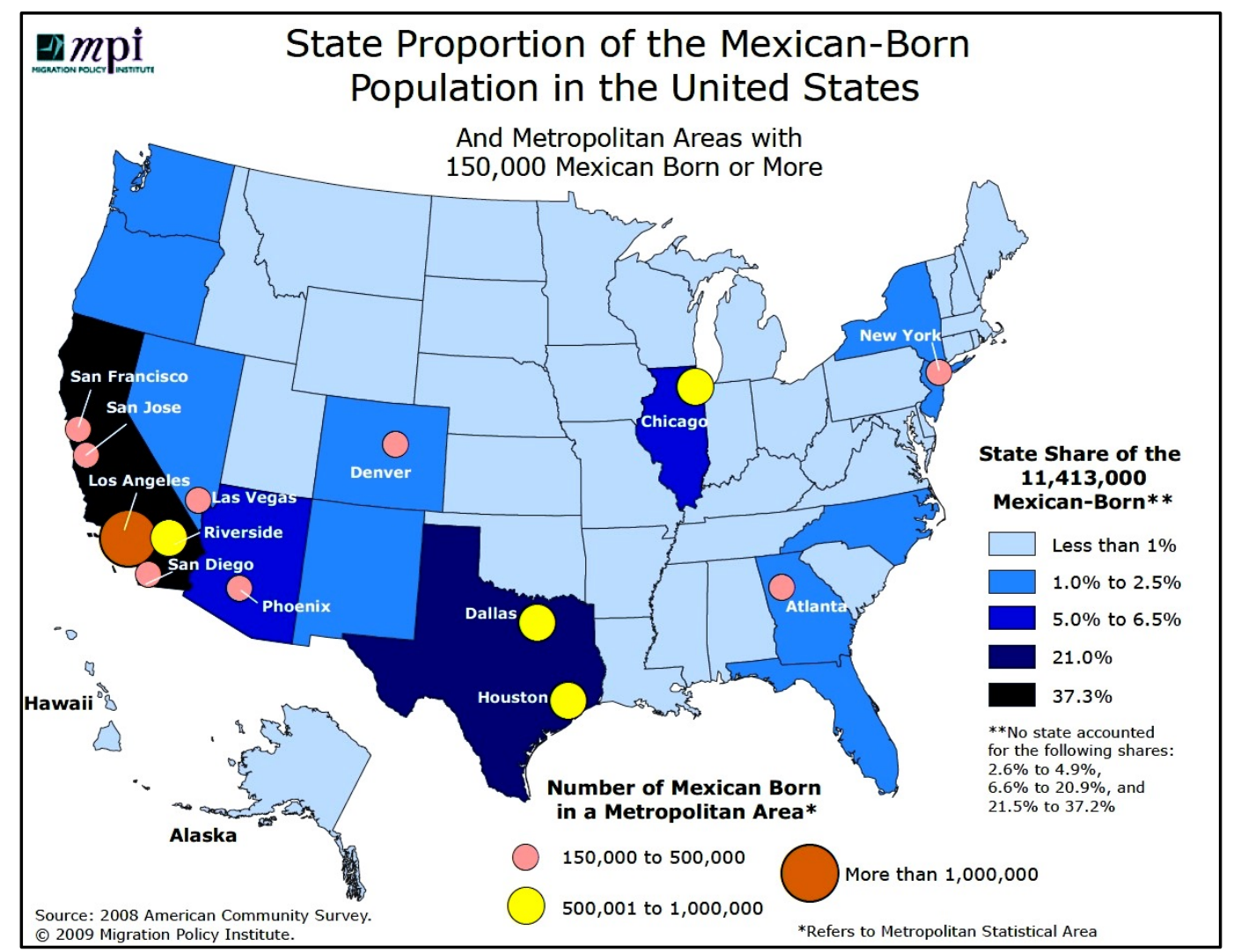

Figure 1. State Proportion of the Mexican-Born population in the USA. Source: United States' Migration Policy Institute, 2012.

graphy National Institute) announced the following information:

1) Until January 2011, there were about 11.5 million unauthorized migrants in the US; 59\% of them (6.8 millions) were Mexican-born.

2) Of the total of inhabited homes in the US in 2011, in 4.7\% (5.4 million) there is, at least, 1 Mexican-born.

3) Of the 5.1 million homes in the US, including the ones where at least there's one Mexican-born in the main household, in $63.8 \%$ there is a chance of family break-up caused by the migratory situation of its members.

Due to the great and growing number of migrants around the world and the consequences of the migration phenomenon at every national level, the United Nations General Assembly enacted December 18th as International Migrant's Day. On the occasion of the date, Mexico's Statistics and Geography National Institute (INEGI) showed a selection of statistic information about migration and the country's national and international migrants.

In the present case, the major emphasis of the mass media, researches and studies made are about economic issues, nevertheless, there are also other aspects of great relevance which have less media attention, as the study of migrant's health, social implications and impact in public security problems. One of the objectives pursued by the present work is to place these axes into the discussed theme about migration's study.

This work has been organized according to the following research method:

\section{Research Method}

We made a meta-analysis in the literature in last 5 year in the following data banks: EBSCO, Emerald, ProQuest, Scholar Google and Elsevier, analyzing the following analysis categories: Economic, Social, Health and Public Security implications.

\section{Results Myths about Migration}

There are 4 myths about Mexicans' migration to the United States in the described analysis categories: 


\subsection{Economic Myth}

Mexicans' migration has negative effects for the United States because migrants make the labour market devaluate by accepting work conditions and salaries below the standards, and establishes an unfair competition for native workers, affecting them by a generalized wages decrease.

As a result of this effect, remittances are an economic bleeding for the US being Mexico the only beneficiary. The reasons of migration are due to Mexico's high unemployment rate and the huge wages differences.

\section{Realities about migration's economic aspects}

The findings let us know that this myth is wrong, due to the following reasons:

The impact in the United States' economy is benefic, getting income by direct taxes, namely, by the goods consumption generated by irregular migrants in the receiving country.

The deficit of the service balance registered in 2012 of 13,340 million dollars started by a 16,018 million dollars income and by a 12,720 million dollars outlay. Inside this balance, international travellers account showed a 4333 million dollars surplus, income results of 12,720 million dollars (a 7.2 percent annual growth) and outlays of 8387 million dollars (a 7.1 percent growth compared to 2011's) [13] Banco de México [Banxico], 2012.

Bank of Mexico's balance of payments data show in the balance of payments the income generated by migrant's remittances and a major percentage corresponds to Mexican migrants living in the United States.

This quantity, being already important, is more relevant for this study to demonstrate that taxes paid by migrants in the US almost double the amount sent by remittances in 2008. As shown in Graphic 1, the taxes paid in 2008 where of 52,799 million dollars, a number that almost double the remittances sent of 25,144 million dollars.

This tendency as we can notice has grown higher, which demonstrates that's a false myth to state that migration brings economic benefits only for the country where the migrants come from since, as demonstrated in the graphic, for each dollar sent to Mexico in 2008, United States earned two.

Incomes for remittances in years before 2008 had been developing in a growing way and the decrease of them was an effect of US' mortgage crisis, bringing as a major consequence a decrease in goods consumption which turned in a smaller production and a smaller economic growth, resulting in an immediate negative impact for Mexico's economy because the majority of remittances come from the United States.

Therefore, we can say that Mexican migrants improve the economic welfare of American Society by contributing with a large amount of taxes generating the strength of United States' inner market, even when a part of the irregular migrants don't have public health nor public education access, mainly.

\subsection{Myths about Social Implications}

Migrants who have as destination the United States' main cities generate large distortions in urban centers of the

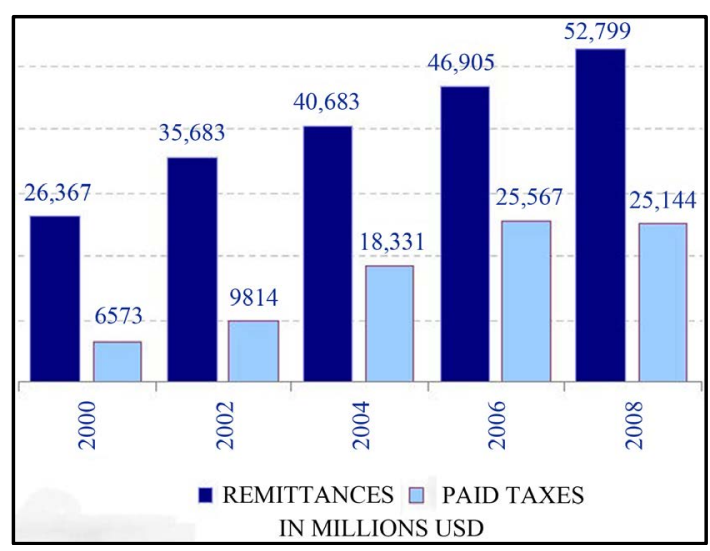

Graphic 1. Remittances and taxes paid by Mexicans in the United States. Source: [14] Albo, A. \& Ordaz, J. (2011, May). Economic effects of migration in the destination country. Benefits of Mexican migration to the United States. BBVA Research. Work Document Number11/17. P13. 
country, while Mexico receives the benefits of remittances that help improving the living conditions and diminishing the food and patrimonial poverty mainly, of migrants' family.

\section{Realities about social impacts}

In Mexico, researches reveal that the worst social effects generated by migration phenomenon are the total family disintegration of some families and, in the worst cases, entire communities. When talking about migration, one can mistakenly assume that there are no social aftermaths or that they are minimized before the economic effects; nevertheless, the social effects are often devastating in some of the country's communities, especially in agrarian communities.

Family disintegration brings negative impacts for society, the possibility of criminal behavior by the left sons increases, some young people who can't bear the absence of their parents may have behavior issues, which may turn in social problems as juvenile crime, domestic violence, even isolation from society caused by the disappointment of the family model and the clichés this institution represents.

Sometimes mothers look for another job to keep supporting their sons when the father doesn't send money yet, which generates a complete family break-up, even sometimes the mothers are forced to prostitute themselves in order to have an extra income. Also amazing is the growth of young single women and mothers with children in the last years, some of them in search for their husbands, boyfriends, friends, couples, others on the other hand, determined to complement the economic income received from their couples or some others just to live the adventure of irregular migration to have an income and support their parents, brothers or looking for a better living condition, not founding it in their homeland. This have also caused migrations to move a group of people to the greater industrial and commercial developed cities in the United States, namely, places where bigger working power is required, the states with bigger Mexican migrants reception are: California, Texas, Arizona and Colorado, as shown in Chart 1.

Taking a close look to the US (except Illinois) and on the other hand, we observe Mexico's map up to 1845, it seems that there's a national crusade to recover United States, sold under pressure derived by Mexico-USA wars. In summary, while migration has its social benefits, like its fight against poverty, migration process has generated drastic changes in national demography, in mainly rural little towns or those of native origins, men have virtually disappeared, and these little towns have become women, little children and aged people's communities, for example "Jicotlán" in Oaxaca state, just to mention 1 of hundreds of communities under the same situation throughout national territory. Therefore, is a myth with no foundations to state that migration brings only social benefits to the families who receive migrant's remittances, without considering the negative effects in the societies.

\subsection{Myths about Health}

Mexican migrants make United States' health care services collapse; taking advantage of a health system they didn’t help building.

\section{Realities about migrant's health}

Migrants' health issue has a lack of bibliography in the consulted databases; therefore the information showed is from many years ago.

United States has one of the most uneven public health systems of the developed world. The latter is a consequence of a Social Security regime fundamentally based on the private sector, while State's responsibility is to take care of the most vulnerable and poor groups who fill the established eligibility criteria to have access to the public programs benefits. In the migrant population case, migration status and legal residence time in the country also affects. [15] Consejo Nacional de Población, [CONAPO], 2009.

Chart 1. Top Mexican-inhabited 5 states in the US.
\begin{tabular}{ccccccc}
\hline Origin \\
MEXICAN & Total & First & Second & Third & Fourth & Fifth \\
Area & UnitedStates & California & Texas & Arizona & Illinois & Colorado \\
Population & $31,798,258$ & $11,423,146$ & $7,951,193$ & $1,657,668$ & $1,602,403$ & 757,181 \\
\hline
\end{tabular}

Source: Top Five States for Detailed Hispanic or Latino Origin Groups with a Population Size of One Million or More in the United States: 2010 obtained from http://www.census.gov/prod/cen2010/briefs/c2010br-04.pdf 
The quantity in millions of children under 18 years old without health security in the United States is shown in the following Graphic 2, according to their parent's origin and race.

As proved in Graphic 2, child population without health security, in Mexicans' born case, is higher in ratio compared to White and Afro-American natives' born, according to the percentage of population who have health security. This is an absolute proof of the falseness of the collapse of the USA health system caused by Mexican migrants' myth, it's false and on the contrary, they bring benefits to the health system by contributing with their taxes, money they're not recovering in health services.

There are other aspects we can't show in numbers as they are, emotional negative states of mind, being these the main stage adding to the subsequent physical diseases, adding also, isolation from the society of origin since from the moment he leave his country, the migrant is legally victim of abuse and harassment, and when he arrives to the destination country, the encounter with his employers is denigrating, because of the low wage, health care services and employment benefits due to his irregular migration status.

As [17] Bezares (2002) wrote:

Migrants are still victims of "enganchadores", "coyotes", or "polleros", which promising to take them to "the other side", ask them for high sums of money, deceiving them a lot of times, leaving them in the desert, sexually abusing them-specially on women-or involving them in prostitution or drug trafficking events.

"In some cases this characters even induce them to consume any kind of drug, with the excuse of lowering the fatigue or the hunger while crossing the border” [18] Najar, 2002.

Because all of this, it's a myth that Mexicans take advantage of United States' health system, where their own people needs' aren't totally addressed.

\subsection{Myth about Public Security and Respect for Migrants' Human Rights}

Mexican migrants are mistreated by American authorities and, on the contrary, foreigner migrants transiting in Mexico are warm welcomed and well-treated, according to Mexican hospitality standards.

\section{Realities about public security and respect for migrants' human rights}

One of the major challenges for the present federal public administration about to conclude is the National Security issue and the inner Mexican migration. "According to [19] INEGI in 2010, Mexico had 3,290,310 inner migrants, meaning this, migrants in transit. Mexico-USA migration route is the most used worldwide" [20] OIM, 2010.

According to Mexico’s National Migration Institute [21] Instituto Nacional de Migración [INM], 2011 about 140 thousand irregular migrants arrive to Mexico per year, most of them from Central America. Most of these international migrants transit through Mexico having the US as destination, which is the international-migrant

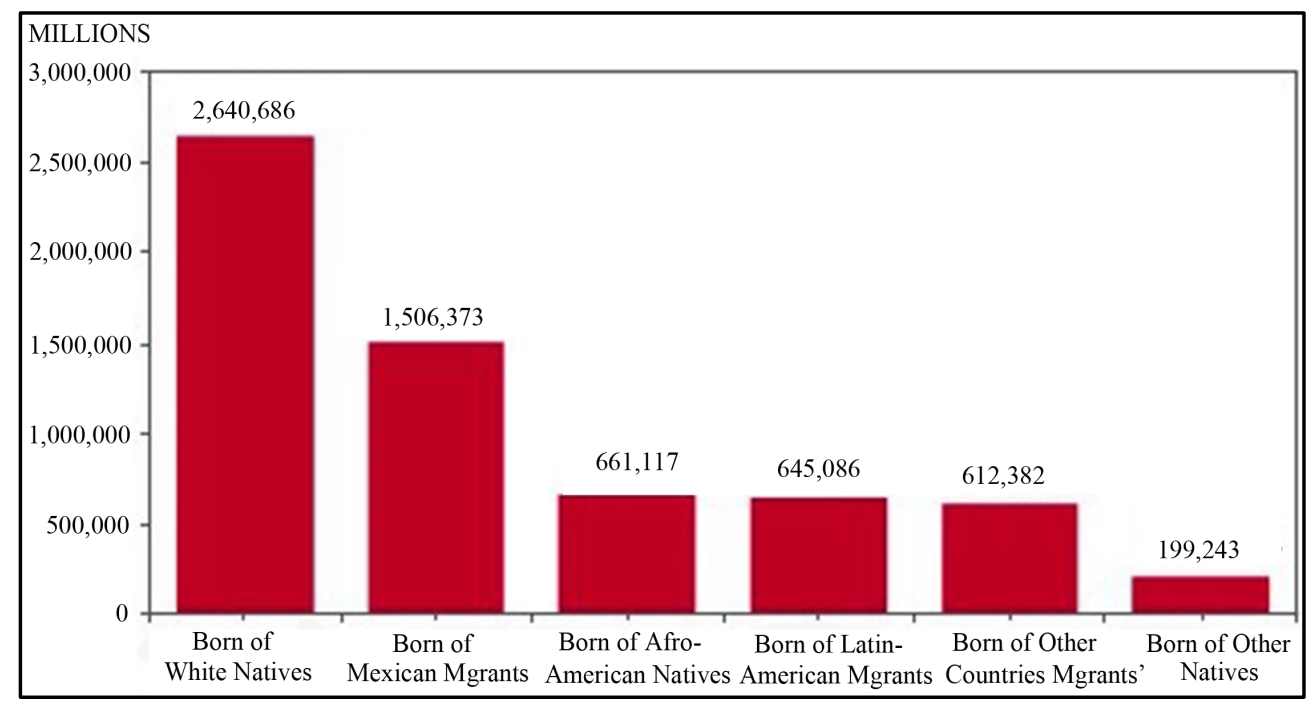

Graphic 2. Childrenunder18 years old without health security in the United States according to their parents' origin and race. Source: [16] CONAPO's estimations based in the Bureau of Census, Current Population Survey (CPS), March 2008. 
most populated country, about 42.8 million, and at least one quarter of they are Mexican. [22] INEGI, 2010The irregular condition and the routes transited throughout Mexico by migrants imply huge chances of robbery, physical, sexual and psychological aggression; intimidation; threats; illicit traffic; human traffic; corruption and extortion; destruction or confiscation of documents; random detention and, with an accelerated growth in the present years, kidnapping, which includes several of the mentioned risks.

Migrants' kidnapping is a growing issue being documented by some "migrants' homes" and shelters placed along the migratory route, Human Rights Centers, Civil Society Organizations and Human Rights Commissions in a Federal and State level ([23] González, 2011).

National Human Rights Commission [24] Comisión Nacional de Derechos Humanos [CNDH], 2010 has documented in its first Special Report about the issue, a number of 9758 kidnapped migrants from September, 2008 to February, 2009; therefore more than 1600 kidnapped persons per month, but for the period between April and September 2010, this number increased to 11,333, in other words, almost 1900 persons per month.

The latter information proves that brutality and abuse being exclusive of the American migration authorities is a myth, because in Mexico several abuses to migrants' civil rights are committed, and sometimes with more viciousness.

\section{Conclusions}

This research demonstrates that the four myths about economy, social impacts, health and public security are false.

The reality is that migrants make large contributions to the receiving country's economy through taxes and their contributions in supporting the retirement funds.

Migrants' origin communities face catastrophic effects in their unity and family integration because of the migration of young women and men that, by leaving their homes, create communities inhabited by only women, aged people and children without parental figures. Economic benefit doesn't help healing the warmth and partnership that characterizes Mexican families and that has been one of the axes of social stability in our country for centuries.

In health issues, Mexicans only use American health services exceptionally, due to their high cost, and take serious risks derived from sexually transmitted diseases that leave them vulnerable. If US authorities aren't able to offer a health system to their own population, they won't do it to foreign migrants.

About the public security issue, although there are a few documented cases of brutality and discrimination with wide media coverage, Central America's migrants take terrifying risks in their way to USA's border, and even when this violence is not from Mexican authorities but from criminal organizations, there are cases of extortion and abuse that only until the recent creation of the new Migratory Law (2011) have started being palliated, therefore according the law, inhabitants who reside or are just travelling through Mexico, even illegal ones, aren't different in health, education or, much less, cultural or racial aspects because they migrate for the same reasons Mexicans do and, therefore, they must be protected and attended in the same way as Mexican natives.

\section{References}

[1] Delgado, R. and Stefancic, J. (2000) Critical Race Theory: The Cutting Edge. Temple University Press, Philadelphia.

[2] Valdes, F. (1997) Foreword: Under Construction. LatCrit Consciousness, Community, and Theory. California Law Review, 85, 1087-1142. http://dx.doi.org/10.2307/3481057

[3] Johnson, K.R. (1995) An Essay on Immigration Politics, Popular Democracy, and California's Proposition 187: The Political Relevance and Legal Irrelevance of Race. Washington Law Review, 70, 629.

[4] Henderson, T.J. (2011) Mexican Immigration to the United States. A Companion to Mexican History and Culture. 604-615.

[5] Schwalbe, K. (2010) Mexican Immigration to the United States. Doctoral Dissertation, University of Delaware, Newark.

[6] Martinez, D. and Slack, J. (2013) What Part of “Illegal” Don’t You Understand? The Social Consequences of Criminalizing Unauthorized Mexican Migrants in the United States. Social \& Legal Studies, 22, 535-551. http://dx.doi.org/10.1177/0964663913484638

[7] Peri, G. (2012) The Effect of Immigration on Productivity: Evidence from US States. Review of Economics and Statis- 
tics, 94, 348-358. http://dx.doi.org/10.1162/REST_a_00137

[8] Annan, K. (2006) Report on Migration and Development. http://www.cinu.org.mx/prensa/especiales/2006/Migracion/indexmigracion.htm

[9] Zúñiga, E., Leite P. and Nava, A. (2004) Migrations’ New Era. Characteristics of International Migration in Mexico. CONAPO, Mexico.

[10] Ramírez, J. (2003) There’s a National debt to ex braceros. Published in MASIOSARE, supplement of La Jornada newspaper.

[11] American Community Survey 2010, US Census Bureau (2012) The Foreign-Born Population in the United States: 2010. http://www.census.gov/prod/2012pubs/acs-19.pdf

[12] INEGI (2012) Mexico’s National Account System Mexico. National Institute of Geography.

[13] Banco de México (2012) Report about Mexico US Migration. http://www.banxico.org.mx/estadisticas/index.html

[14] Albo, A. and Ordaz, J. (2011) Economic Effects of Migration in the Receiving Country. Benefits of Mexican Migration to the United States BBVA Research. Workdocumentnumber 11/17. Sistema de Información sobre Migración Internacional y Desarrollo (SIMDE).

[15] CONAPO (2009) Migration and Health. http://healthpolicy.ucla.edu/publications/Documents/Forms/AllItems.aspx?RootFolder=\%2fpublications\%2fDocument s\%2fPDF\&FolderCTID=0x0120000B8E47D3E58BFB40B946F261A0087524

[16] CONAPO (2008) Based on Bureau of Census, Current Population Survey (CPS). http://www.census.gov/prod/cen2010/briefs/c2010br-04.pdf

[17] CONAPO (2004) Migrations’ New Era. Features of International Migration in Mexico.

[18] Bezares, P. (2002) Risks of Migration: Human Rights and Vulnerable Groups, National Migration panel in Guatemala Menamig Bulletin, Number 21.

[19] Najar, A. (2002) Children Migration: The Other Face of the Phenomenon. The most vulnerable. La Jornada Newspaper, Masiosare Supplement 251.

[20] INEGI (2010) National Institute of Geography. http://www3.inegi.org.mx/sistemas/temas/default.aspx?s=est\&c=21702

[21] OIM (2010) World Migration Report 2010.The Future of Migration: Creation of Change Abilities Geneva. http://www.oas.org/es/cidh/prensa/comunicados/2014/054.asp

[22] Instituto Nacional de Migración (2011) Notes about Migration: Central America Migrants’ in Irregular Transit through Mexico. Estimates and General Features. http://www.oxfammexico.org/wp-content/uploads/2013/06/APUNTES N1 Jul2011.pdf

[23] González A. (2011) Kidnapping of Migrant People in Transit through Mexico. http://www.google.com.mx/url?sa=t\&rct=j\&q=\&esrc=s\&frm=1\&source=web\&cd=2\&ved=0CC4QFjAB\&url=http\%3 A\%2F\%2Fwww.azc.uam.mx\%2Fpublicaciones\%2Falegatos\%2Fpdfs\%2F76\%2F83-10.pdf\&ei=TS9yU4z1GKm_8gG w3oDICg\&usg=AFQjCNH7I9458tTnueL9UK3FQtI1I6uwMQ

[24] CNDH (2010) Kidnapping of Migrant Peosple. http://www.centroprodh.org.mx/index.php?option=com_docman\&task=doc_download\&gid=8\&Itemid=92\&lang=es 